Supporting Information for

\title{
Influence of silica particle size on the corrosion behavior of electroplated silica-Ni hybrid layer
}

\author{
Rong Yang, Pengyuan Xu, Gang Xin* \\ Faculty of Chemical, Environmental and Biological Science and Technology, \\ Dalian University of Technology, Dalian 116024, China \\ Corresponding Author's Email: gxin@dlut.edu.cn
}

\section{Contents}

1. The main components of Q235 steel.

2. Hull Cell test.

3. Calculation of porosity 


\section{The main components of $Q 235$ steel}

Table S1. Chemical composition of Q235 steel.

\begin{tabular}{lllllll}
\hline Element & $\mathrm{C}$ & $\mathrm{Mn}$ & $\mathrm{Si}$ & $\mathrm{S}$ & $\mathrm{P}$ & $\mathrm{Fe}$ \\
\hline Composition & 0.17 & 0.45 & 0.33 & 0.040 & 0.035 & Balance \\
\hline
\end{tabular}

\section{Hull Cell test}

A $267 \mathrm{ml}$ Hull cell was used to electroplating nickel under the high current conditions. The apparent morphology of the cathode near the anode is shown in Figure S1. The results show that the nickel crystals formed during the electroplating process mainly grow in the direction of dendrites, and pores are formed between the dendrites.

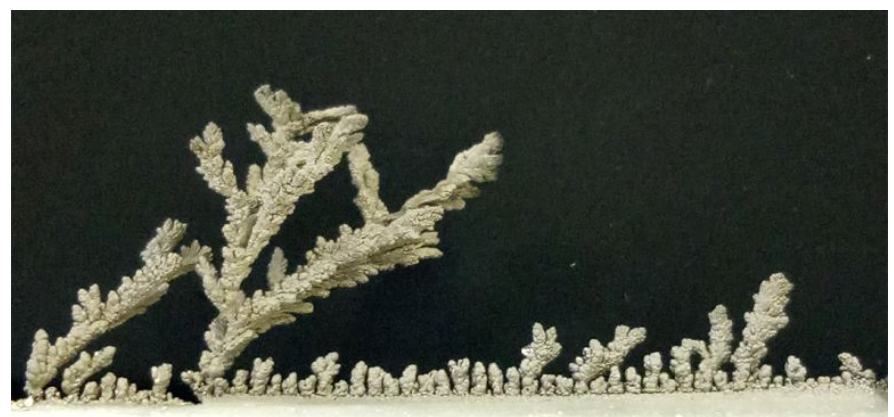

Figure S1. Results of Hull cell test

\section{Calculation of porosity}

According to the FESEM results, the porosity of the nickel layer and the hybrid layers were calculated using the gray scale method, the results are shown in Table S2. The porosity of the pure nickel coating is $2.7 \%$, and the porosity of the hybrid layer added with silica particles is less than $0.5 \%$, and the difference is very small. The results show that the size of the silica particles has little effect on the surface porosity.

Table S2. Porosity of the pure Ni and silica-Ni layers.

\begin{tabular}{cccccc}
\hline Samples & $\mathrm{Ni}$ & $\begin{array}{c}10 \mathrm{~nm} \text { silica- } \\
\mathrm{Ni}\end{array}$ & $\begin{array}{c}50 \mathrm{~nm} \text { silica- } \\
\mathrm{Ni}\end{array}$ & $\begin{array}{c}100 \mathrm{~nm} \text { silica- } \\
\mathrm{Ni}\end{array}$ & $\begin{array}{c}150 \mathrm{~nm} \text { silica- } \\
\mathrm{Ni}\end{array}$ \\
\hline Porosity (\%) & 2.93 & 0.38 & 0.45 & 0.29 & 0.24 \\
\hline
\end{tabular}

